In total the reasonably assured and estimated additional uranium resources at Kvanefjeld are now 43850 tons contained in rocks with an average grade of approximately $320 \mathrm{ppm} \mathrm{U}$.

The amount of known uranium resources on Kvanefjeld has been increased considerably, and the deposit, although of low grade, now belongs to the class of medium to large uranium deposits of the world.

\title{
References
}

Ferguson, J. 1964: Geology of the Ilímaussaq alkaline intrusion, South Greenland. Description of map and structure. Bull. Grønlands geol. Unders. 39 (also Meddr Grønland 172,4) $82 \mathrm{pp}$.

Sørensen, H., Hansen, J. \& Bondesen, E. 1969: Preliminary account of the geology of the Kvanefjeld area of the Ilimaussaq intrusion, South Greenland. Rapp. Grønlands geol. Unders. 18, $40 \mathrm{pp}$.

Sørensen, H., Rose-Hansen, J., Nielsen, B. L., Løvborg, L., Sørensen, E. \& Lundgaard, T. 1974: The uranium deposit at Kvanefjeld, the Ilímaussaq intrusion, South Greenland. Rapp. Grønlands geol. Unders. 60, 54 pp.

\section{Geological, geochemical and ecological research in the Ilímaussaq region, South Greenland}

\section{Compiled by John Rose-Hansen and Henning Sorensen}

In 1977 field work was concerned with the lujavrites and kakortokites of the south-eastern part of the Ilímaussaq alkaline intrusion (see Andersen \& Bohse, this report), pegmatites and veins within the intrusion, the Narssaq intrusion situated to the west of the Ilimaussaq intrusion, and the environmental geochemistry and the ecology of the Narssaq region. Preliminary results of the field work and of some of the laboratory investigations are reported below.

It should also be mentioned that a diamond drilling programme was carried out in the uraniferous rocks of the Kvanefjeld area in the northern part of the Ilímaussaq intrusion (see Nyegaard, this report).

\section{Pegmatites and veins (Sven Karup-Møller)}

Detailed mapping of a large naujaite pegmatite at the head of Kangerdluarssuk fjord was carried out. The pegmatite is complex composed of the following zones from outside inwards: (1) eudialyte zone, (2) arfvedsonite zone, (3) aegirine zone and (4) sodalite zone. The zones are cut and partly replaced by a late albititic phase during which a number of rare minerals have developed e.g. steenstrupine and epistolite. Samples were collected for geochemical and mineralogical studies from the major pegmatite, and several pegmatites and veins within the naujaites and kakortokites. 


\section{Mapping in the Narssaq intrusion (Dan Olsen)}

The field work initiated in 1976 was continued. Mapping in the northern part of the intrusion between Narssaq Elv and Bredefjord was completed. In this work the unpublished observations of J. W. Stewart, GGU, were of considerable use.

The area mapped in 1977 comprises essentially the same rock types as described previously (Rose-Hansen \& Sørensen, 1977, p. 73). However, the regular pattern found in 1976,

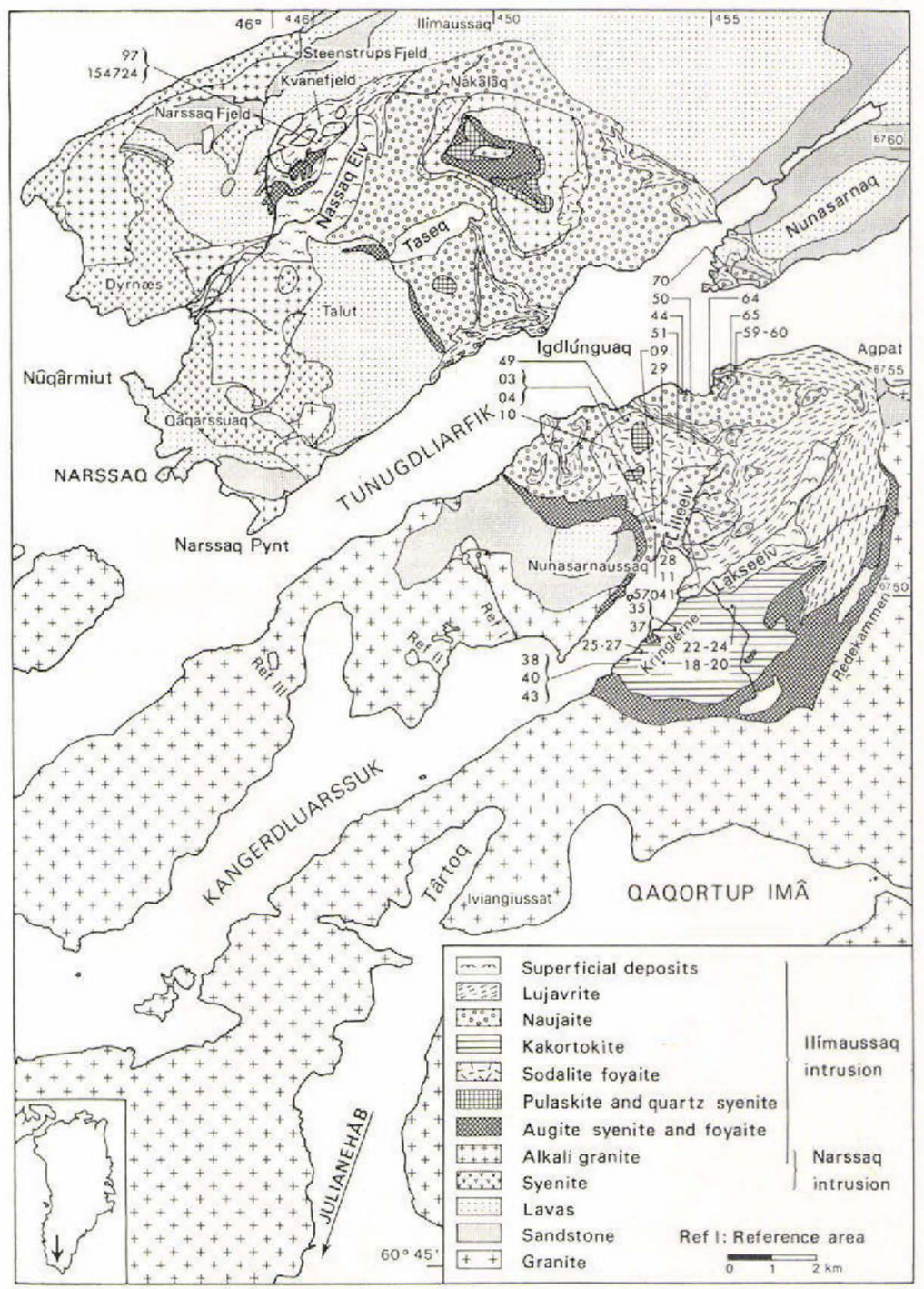

Fig. 25. Geological sketch map of the Ilímaussaq alkaline intrusion, South Greenland. To obtain the full GGU sample numbers, the figure 1543 is placed in front of the two-figure numbers. 
with thick units of coarse pink-grey syenite with fine-grained feldspar porphyritic margins against earlier units, could not be traced beyond the Narssaq main fault although a similar pattern was found at several places.

The contacts between the various syenites (and quartz syenites) are generally sharp but completely gradational contacts do exist. In places a sharp contact can imperceptibly merge into a gradational one. These internal contacts are never chilled, indicating that the whole syenite complex was emplaced within a short time span. At several places small rounded bodies of syenogabbro or mafic syenite are associated with anorthosite. A rather mafic syenite with a large but variable amount of plagioclase xenocrysts is one of the youngest syenite intrusive phases.

A large, mostly homogeneous body of alkali granite appears to be the last major pulse of magma. It is cut by brown doleritic dykes, but trachytic dykes, which in places are numerous in the syenite complex, are absent. The alkali granite has with few exceptions a nearly constant grain size right up to the contact independent of the wall rock.

Environmental geochemistry and ecology (Christian Overgaard Nielsen, John Rose-Hansen \& Henning Sørensen)

This project undertaken jointly by GGU and the Danish Natural Science Research Council (SNF) was initiated in 1974 (Bohse et al., 1975; Nielsen et al., 1976; Rose-Hansen \& Sørensen, 1977). In 1977 the major activities concerned laboratory work and only restricted field work was undertaken in order to collect supplementary data.

The field work comprised:

(1) Continuous registration of a number of climatological and hydrological parameters and collecting of water samples from streams and precipitation.

(2) Limnology.

These activities and some of the laboratory studies will be briefly described in the following.

\section{Hydrology and climatology (Niels P. Christensen)}

In five rivers (Narssaq Elv, Taseq Elv, Kvaneelv, Lilleelv, and the river in reference area III, fig. 25) weekly discharge measurements were made, precipitation frequently registered, while air temperature, air pressure and humidity were recorded continuously. River water samples were collected from the five rivers for chemical analysis. In the reference area III and Lilleelv drainage basins precipitation was measured and collected for analyses at intervals of altitude of $100 \mathrm{~m}$. In three other locations water was collected for chemical analysis of the precipitation and of the dust content.

Two new instruments were attached to the datalogger in reference area III; a barometer and an integrating radiation sensor. Two of the transducer units, those of the reference area III stream and the precipitation gauge at Dyrnæs, were dismounted due to malfunctioning, which was probably caused by ice-shattering of the membranes. New ones will be installed in 1978. 
Limnology (Henrik Mosegaard, Peter Mæhl \& Bent H. Nielsen)

The aim of the 1977 field work was to further the limnological investigations of 1976, in particular the ecological research in a selected lake, 'Lake 280' in the Kangerdluarssuk area. Emphasis was given to the phytoplankton primary production, where an improved method for $\mathrm{CO}_{2}$-determination was applied, as well as to the investigations of the benthic fauna (Chironomidae, Diptera), which were extended to include hatching and rearing of larvae in the laboratory.

Several experiments were carried out to estimate the benthic primary production by measuring changes in oxygen concentration in an enclosed water body in contact with the sediment surface. Furthermore the population of arctic char (Salvelinus alpinus) was investigated by capture/recapture methods. The phytoplankton, zooplankton and water sampling programme was continued in two other lakes ('Lake 95' and 'Lake 280') in the Kangerdluarssuk area.

The fauna of five rivers (Taseq Elv, Kvaneelv, Narssaq Elv, Lilleelv and Lakseelv) was closely examined. At each station the fauna of different habitats (e.g. surface of boulders, moss carpets) was sampled. This should provide an improved basis for detecting changes in the species composition as a consequence of changes in the environment.

\section{Chemical analysis (Raymond Gwozdz)}

More than 1000 samples of biological materials, rocks, minerals and water collected in 1974,1975 and 1976 have been analysed by instrumental neutron activation analyses of 39 elements. These analyses have been supplemented with delayed neutron counting following neutron activation and when necessary by X-ray fluorescence analysis. The data are being processed by means of computer programmes.

\section{Botanical investigation (Jon Feilberg)}

No field work was carried out in 1977 but compilations of maps of vegetation analyses and vegetation types of the region were completed in 1977.

\section{Marine biology (Martin Munk Hansen)}

Most of the samples of bivalves collected in 1976 were analysed by instrumental neutron activation analysis. To assist in the interpretation of the analytical data a literature analysis concerning the effect of accumulation, excretion, toxicity of heavy metals on bivalves has been made (Hansen, 1977).

This literature study is based on computer programmes: a retrospective one (BIOSIS) and two continuing ones (BIOSIS and ISI). Preliminary studies of heavy metal clearance by Mytilus have been made on Mytilus transplanted from the Narssaq area to Isefjord, Denmark. With regard to the study of the toxicity and the accumulation of heavy metals in bivalves a bioassay plant has been designed in co-operation with engineers from Risø National Laboratory, Roskilde, and physiologists from the August Krogh Institute, Copenhagen. 
Weathering and soil formation in the Narssaq region (Carsten Langtofte Larsen \& Leo Nielsen)

Weathering and soils were studied at several localities during the summers of 1974, 1975 and 1976. Some results of this field work and the subsequent laboratory studies are given below (Larsen, 1977).

The sediments within the intrusion may in general be classified as belonging to an alluvial fan sedimentation system within an area of isostatic rebound and denudation.

The syenites and nepheline syenites of the Ilímaussaq intrusion are covered by loose debris supporting very few scattered plants. Soil development is very primitive and scarce and no soil horizons are developed. Some areas underlain solely by lujavrite support a more coherent vegetation. The development of horizons is very weak or missing in these soils as the brown colour of free Fe-oxides masks the dark colour of organic material. The humus content as well as the colouration diminish gradually downwards in these profiles. A proper coherent vegetation is found in the river valleys and on the big alluvial cones to the north of Tunugdliarfik fjord. Brown coloured soils occur on the lower terraces, podsolic soils on the higher ones. Podsolic soils are also abundant on the Precambrian granites surrounding the intrusion.

The soils are tentatively grouped into syrosems and rankars (both lithosols) and brown-soils and podsols (classification according to Kubiena, in Scheffer \& Schachtschabel, 1973).

The lithosols, which cover most of the intrusive rocks, have a narrow range of $\mathrm{pH}$ values from 5.2 to 6.6 measured in $0.01 \mathrm{~N} \mathrm{CaCl}_{2}$ and an almost uniform $\mathrm{pH}$ throughout the profile. The podsolic soils developed on alluvial deposits and granitic parent material show a wider range. The $\mathrm{pH}$ of the top horizon varies from 3.9 to 4.5 and the $\mathrm{pH}$ increases rapidly over the first $10 \mathrm{~cm}$ of the podsolic profile. The granitic soils have a pH of 5.6 at the bottom whereas the alluvial soils have $\mathrm{pH}$ values about 6.6 to 6.9 at the bottom.

All soils are sandy in character. The clay size fraction amounts to less than 5 per cent and true clay minerals are probably rare. Only chlorite and an illite group member were revealed by X-ray diffraction analysis. These two minerals are very subordinate constituents in the rocks of the intrusion.

Chemical analyses of the less than $0.177 \mathrm{~mm}$ fraction of 66 individual soil samples from 22 profiles have been carried out together with 12 analyses of the less than $2 \mu \mathrm{m}$ fraction. $\mathrm{Nb}$, $\mathrm{Ta}, \mathrm{Zr}, \mathrm{Hf}, \mathrm{Li}, \mathrm{Rb}, \mathrm{Cs}, \mathrm{Sc}, \mathrm{Y}$ and the lanthanides have been determined by means of instrumental neutron activation and $\mathrm{X}$-ray fluorescence analyses. The results have been grouped according to parent material, soil type and type of horizon.

$\mathrm{Nb}$ and $\mathrm{Ta}$. The bulk amount of $\mathrm{Nb}$ and $\mathrm{Ta}$ in the rocks is connected with eudialyte and rinkite. The rock $\mathrm{Nb} / \mathrm{Ta}$ ratio is about 16 . The concentration of $\mathrm{Nb}$ in soils developed on nepheline syenites is $313 \mathrm{ppm}$ on an average. In soils on granitic material the average is 149 ppm. Within the soil profile the $\mathrm{Nb}$ soil/parent material (taken as the C-horizon) ratio is always below 1 , ranging from 0.26 to 0.95 . The general trend is an increasing $\mathrm{Nb}$ concentration with depth. The distribution of $\mathrm{Ta}$ follows $\mathrm{Nb}$ very closely and the $\mathrm{Nb} / \mathrm{Ta}$ ratio is virtually constant for all soils varying between 18.6 and 21.1. However, in the podsolic profiles the $\mathrm{Nb} / \mathrm{Ta}$ ratio increases with depth from 17.3 to 22.6 in one soil on kakortokite, 
and from 16.6 to 25.3 and from 20.0 to 26.1 in two soils on alluvium. Both $\mathrm{Nb}$ and $\mathrm{Ta}$ are supposed to be subject to transportation downwards in the profile.

$\mathrm{Zr}$ and $\mathrm{Hf}$. The concentration of $\mathrm{Zr}$ and $\mathrm{Hf}$ is particularly high in eudialyte but also aegirine and arfvedsonite contribute substantial amounts to the soil. The average concentration of $\mathrm{Zr}$ in soils developed within the intrusion is 3.85 per mille. The concentration in soils on granite is $1.55 \mathrm{per}$ mille. The $\mathrm{Zr}$ soil/parent material ratio varies from 0.65 to 0.95 for soils within the intrusion and soils on granite. The general trend within the profile is an increase in concentration with depth. $\mathrm{Zr}$ is depleted in the clay size fraction compared with the less than $0.177 \mathrm{~mm}$ fraction. The $\mathrm{Zr}$ clay size fraction/soil ratio for naujaitic soils ranges from 0.07 to 0.5 ; for lujavritic soils from 0.2 to 0.7 . It is evident from the $\mathrm{Zr}$ soil/parent material ratio, that $\mathrm{Zr}$ is carried downwards in most profiles and either lost or concentrated in the illuvial horizon. Hf follows $\mathrm{Zr}$ closely in the soils. The $\mathrm{Zr} / \mathrm{Hf}$ soil ratio varies from 44 to 59, except for soils on black lujavrite, in which the ratio is 190 .

Yttrium and the lanthanides. The content of lanthanides in the rocks of the intrusion can be considered unique. A great number of lanthanide containing minerals occur in the rocks, for instance rinkite, steenstrupine, monazite and rhabdophanite. Besides these minerals, eudialyte also contains a considerable amount of lanthanides.

The sum of the detected lanthanides (excluding $\mathrm{Pr}, \mathrm{Gd}, \mathrm{Dy}, \mathrm{Ho}, \mathrm{Er}$ ) in the soils within the intrusion is on average 0.22 per cent. The same value for the granitic soils is $590 \mathrm{ppm}$.

A comparison of the chondrite-normalised pattern of the bedrock with that of the soil developed on it shows a great similarity for all soil horizons. Most soils within the intrusion are depleted, especially in lanthanum and terbium (soil/rock ratios from 0.2 to 0.9 ). Some soils on naujaite and all soils on granitic parent material are enriched in lanthanides. All horizons, especially the upper ones, show increasing enrichment towards the heaviest members of the lanthanide group. The lanthanide concentration always increases with depth in the soil profiles, except for the eluvial horizons of the podsolic soils, which show minimum concentrations.

Too little is known about the behaviour of the individual lanthanides in the soils to give an exhaustive comment on the distribution. Eu follows the content in the bedrock closely on a chondrite-normalised basis, but shows a relative enrichment in the podsolic soils. The enrichment is most pronounced in the upper most acidic horizons.

\section{References}

Bohse, H., Larsen, L. M., Rose-Hansen, J., Nielsen, C. O. \& Sørensen, H. 1975: Current research on the llimaussaq alkaline intrusion, South Greenland. Rapp. Grønlands geol. Unders, 75, 81-83.

Hansen, M. M. 1977: Muslingers forhold overfor tungmetaller. Unpubl. thesis, Univ. Copenhagen.

Larsen, C. L. 1977: A reconnaissance study of the exogenous environment, and the abundance of selected trace elements in the solids of the Ilímaussaq region, South Greenland, Unpubl. Prize dissertation, Univ. Copenhagen, $265 \mathrm{pp}$.

Nielsen, C. O., Rose-Hansen, J. \& Sørensen, H. 1976: Environmental, geochemical and ecological studies in the region around the Ilímaussaq alkaline intrusion, South Greenland. Rapp. Grønlands geol. Unders. 80, 93-97.

Rose-Hansen, J. \& Sørensen, H. 1977: Current research in the Ilímaussaq region, South Greenland. Rapp. Grønlands geol. Unders. 85, 67-73.

Scheffer, F. \& Schachtschabel, P. 1973: Lehrbuch der Bodenkunde. Stuttgart: Ferdinand Enke Verlag, $448 \mathrm{pp}$. 
N.P.C., R.G., L.N., C.L.L.,

D.O., J.R.-H., H.S.,

Institut for Petrologi.

University of Copenhagen,

$\emptyset$ ster Voldgade 10,

1350 Copenhagen $K$.

J.F.,

Botanisk Museum,

Gothersgade 130,

1123 Copenhagen $K$.

H.M., P.M., B.H.N., Ferskvandsbiologisk Laboratorium, Helsingørgade 49-51, 3400 Hillerød,

Denmark.

S.K. $-M$.

Mineralogisk Institut,

Danmarks Tekniske Højskole, 2800 Lyngby,

Denmark.
C.O.N., M.M.H., Institut for Almen Zoologi, Universitetsparken 15, 2100 Copenhagen $\emptyset$.

Field work on the kakortokites and lujavrites in the Ilímaussaq intrusion, South Greenland

\author{
Steen Andersen and Henning Bohse
}

In the field season 1977 the study of the kakortokites and the lujavrites was continued in the southern part of the Ilimaussaq intrusion. The mapping was extended to the Agpat area (fig. 25) and a number of sample profiles were collected. S. A., assisted by Peder M. Sørensen and Emanuel Kristiansen, worked to the north-west of the river Lakseelv; H. B. and Ingrid Salinas to the south-east of the river.

Mapping on the scale 1:5000 of the kakortokites and the larger part of the main lujavrite outcrop is now completed. Five units have been distinguished (fig. 26). The lower part of the profile - kakortokite to aegirine lujavrite II - has been measured to the south-east of Lakseelv, whereas the higher units are found in the Agpat region. The two subareas are divided by the Lakseelv fault. A similar sequence, but with a different thickness, exists at the head of Kangerdluarssuk (A. Demina, personal communication).

In contrast with the standard map and profile as given by Ferguson (1964), we have divided the aegirine lujavrites into three units: aegirine lujavrites I and II and schlieren lujavrite. Later Ferguson (1970, pp. 30-31) also hesitated to class what is our schlieren lujavrite into the aegirine lujavrites proper.

Aegirine lujavrites I and II are conformable units with a gradual transition and they are merely divisions of the main lujavrite profile. The division can, however, be mapped all over the region, and preliminary chemical analyses confirm the difference between the two rock units. Aegirine lujavrite I forms the lower unit with a thickness of about $80 \mathrm{~m}$. The rock is distinctly laminated and displays a strong fissility. Banding is expressed by variations in the proportions of nepheline and microcline. The rock is fine-grained with grain size decreasing upwards. Aegirine lujavrite II forms two layers (approximately 85 and $35 \mathrm{~m}$ thick) above 